\title{
CAMUS' ART OF TRANSLATION: AN UNRECOGNIZED TALENT ${ }^{1}$
}

Robert Kemp, reviewing the 1957 Angers Festival proclaimed Camus the highlight of the year in French theater: "A distance, l'événement de la saison thêatrale qui s'achève sera peut-être la résurrection - qui, pour beaucoup, est la révélation - d'un homme de théâtre du premier ordre: Albert Camus."2 Camus was indeed a complete "homme de théâtre." Not only did he excel in his favorite genre as actor, director, playwright, and script-writer, but he also left an indelible impression as translator of foreign plays, particularly Spanish. As was also the case in 1953, when he presented his own translation and adaptation of Calderón's La Devoción de la cruz, much of his succes in 1957 was attributed to his excellent version of Lope de Vega's El Caballero de Olmedo. A detailed study of Camus' Le Chevalier d'Olmedo will reveal a very stage-conscious man as well as a faithful, sensitive, and extremely competent translator.

Critics who comment on Le Chevalier d'Olmedo after having discussed La Dévotion à la croix often refer to the latter as a translation but call the former an adaptation. Even Camus, in the preface to Le Chevalier d'Olmedo, states that he followed a path somewhere between a free adaptation and a word by word translation in providing a French text for this play. It would be misleading, however, to call Camus' French version an adaptation because, in spite of numerous changes, he does not delete any important passages from Lope's play. Furthermore, there are no examples of his philosophy permeating this theater of action. And whatever changes he made serve one purpose: to preserve all the intentions of the original playwright while writing a play suited for French actors and especially destined to please French audiences. To call Camus an apologist of the Spanish theater would be more accurate than to consider him an adaptor. He felt that this theater was so full of life and relevance that it belonged on a modern stage, not on a dusty book-shelf. If he changed Lope's play much more than Calderón's, it is simply because he attempted to turn the former's baroque language into natural French prose. His desire was to produce a play whose forceful spoken sentences would still retain the music and beauty of the original rhymed verses.

Roger Quilliot, the editor of Camus' complete works, explains why Camus did not select one of the existing translations when he decided to present the Spanish play: "Il lui semblait que les traductions existantes étaient ou bien insuffisantes et inexactes ou peu théâtrales; or il entendait travailler pour la scène." ${ }^{3}$ Did Camus succeed where others failed? All one needs to do is compare Camus' version to earlier translations, Eugène Baret's, for instance, to be immediately convinced of the superiority of the former. Curiously enough, however, this superiority stems from his fidelity to the original text. Whereas Baret decided on purely subjective and arbitrary grounds what merited translation, what was offensive to 
French audiences, what was worthy of Lope's talent, and what passages needed to be omitted completely or explained in often condescending footnotes, Camus, on the contrary, did not play the role of censor and "purifier" but translated scrupulously Lope's spirit while modernizing somewhat Lope's words. A close look at the original and French texts will attest to Camus' fidelity and excellence as translator.

As the curtain rises Don Alonso is pondering on the nature of love. From the mixture of exaltation and doubt in his monologue, it is evident that he is not engaged in a dispassionate discourse. He is Cupid's last victim. His argument that unilateral love is an imperfect creature reflects the fear that his passion might be unanswered. The Spanish text starts

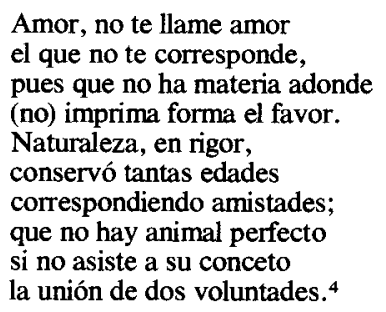

The principal theme of the play is presented right from the very first word, and further strengthened by the poetic form chosen, the redondilla, an octosyllabic stanza of four verses with rhyme $a-b-b-a$, to which Lope usually entrusted the expression of "cosas del amor." ${ }^{5}$ Masterfully he awakens the public's interest in this unnamed character, the object of Alonso's adoration. An atmosphere of expectation and mystery prepares the appearance of this divine creature who together with Don Alonso might achieve a perfect union of "dos voluntades."

The impact and meaning of the entire monologue may escape a modern day audience. Camus' modern diction, on the other hand, is readily understandable: 'Aimer n'est rien, il faut être aimé! L'amour solitaire n'est pas digne de son nom, l'amour sans réponse s'épuise en vain vers sa forme! Mais qu'il soit réciproque, au contraire, et la loi de la nature le fera durable! Y a-t-il sur toute la terre une seule créature parfaite qui n'ait été engendrée par les noces de deux désirs?' (Théâtre, 721). In spite of the loose translation, all the ideas are respected.

The departure from a strict literal translation was imperative in this scene which sets the tone; a scene which must attract and retain the attention of the audience. Camus knew that Lope had achieved this desired goal with the redondilla; the poetic form of excitement and love.

He had to replace its intrinsic strength with a prosaic form which could fulfil the same function. In this case, the rendering of a vividly dramatic impact was far more important than being faithful to the text.

An actor needs what Camus calls "l'attaque" in order to draw the public's attention. Four short staccato sentences, three exclamations, and 
a question, create the theatrical dynamism necessary for this scene. It is a bold beginning totally in keeping with his desire to write a text of action, a deserving rendition of a play emphasizing rapid movement. In Baret's opening scene, Alonso speaks like a philospher methodically analysing the nature of love rather than as a lover torturing himself with the thought that his passion might be unanswered. ${ }^{6}$

One of the salient characteristics of Lope's theater is its insistence on the primacy of movement. In El Caballero de Olmedo, the first act is divided into seventeen scenes developed in five different settings. By the sixth scene, all the main characters have made their appearance. To avoid the impression of chaos on stage, the text should complement the action. Lope's text perfectly supports the physical movement of the play. $\mathrm{He}$ capitalizes on the concise expression of poetry but avoids the monotony of rhymed verse by varying the poetic form according to the sentiment expressed. In the poem Arte nuevo de hacer comedias he summarizes his approach:

Las décimas son buenas para quejas;
el soneto está bien en los que aguardan;
las relaciones piden los romances,
aunque en octavas lucen por extremo.
Son los tercetos para cosas graves,
y para las de amor, las redondillas. ${ }^{7}$

To achieve the subtle changes of mood, the transitions from occasionally pompous language to delicate and enchanting lyrical verses, or the rapid shifts in tone, Lope relied on different poetic forms. As he stated in his Arte nuevo, the selection of a décima over a sonnet is far more than a fortuitous inconsequential choice. In his plays, the former is generally associated with the idea of grievances; the latter, having a greater syllabic count, carries the conception of waiting. Perhaps it could be argued that this correspondence between form and subject is irrational, one of Lope's inventions. But it must not be forgotten that when he wrote his Arte nuevo he was actually describing the method employed in the composition of his four hundred and eighty-three plays. ${ }^{8}$ Hundreds more were to follow! Lope's public was no different from today's television audiences which can predict how a doctor will talk to his patient or how a lawyer will force the true culprit to confess. It is a simple process of conditioning; they responded to stimuli as we do. Repeated association of a redondilla with expression of love would finally establish as most natural this connection between form and subject.

Camus' task was not an easy one. Since poetry is more concise than prose, there existed the danger that the brisk movement of the play would be reduced to a crawl by long tortuous sentences and heavy dialogue. This pitfall was deftly avoided.

In Camus' text most sentences are short or broken into gracefully 
spoken sentences. He often needs to simplify Lope's complex sentence structure. One example taken from a dialogue between Ines and Alonso will suffice to illustrate this technique. Don Alonso, who has been visiting Ines, suddenly realizes that he may be seen leaving her house because the sun will shortly rise. He says:

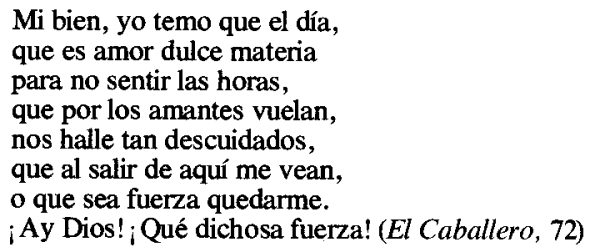

The first sentence, developed over seven verses has one phrase and five subordinate clauses introduced by the conjunction "que". The principal clause in the first verse is separated from its conclusion by the two other clauses thus blurring out the meaning. In Camus' translation of these eight verses, the two original sentences become four, all starting with the subject-verb construction which facilitates recital: "Bien aimé, l'amour est d'une étoffe si fine qu'il laisse couler sans les sentir les heures qui fuient trop vite pour les amants. Je crains que le jour ne nous surprenne. On me verra sortir d'ici ou je serai forcé d'y rester. Douce! mon Dieu, serait l'obligation"' (Théâtre, 765).

Camus also knew how difficult it is for an actor to give the necessary force to a declamation that starts with a subordinate clause or with a present participle. Consequently he not only avoided these constructions in his own text but changed the ones he found in the original.

Ilona Cooms states that for Camus, "un grand thêatre ne pouvait être que celui où l'homme affronte plus que l'homme."9 Alonso's tragedy could not be described more concisely. So outstanding are his virtues, so magnanimous his nature, that his collapse, his failure, could never be provoked by a natural force alone. That Camus recognized the dramatic force of a character such as Don Alonso's and thus strove to write a text that would enhance this quality is admirable, but hardly surprising. What we owe to Camus is having taken Rodrigo's role seriously.

The rejected lover is not a likeable figure; even his drama is humiliating. Whereas Alonso's tragedy is noble because of its transcendental nature, Rodrigo's is vulgarly mundane: he simply fails as a man in a society that glorifies manliness. His attempts to move Ines are met with indifference and contempt; his courage and agility betray him in the arena; his last effort at regaining his dignity is the cowardly act of killing Alonso. But his torment is real. When he begs death to grant him the peace that life has refused him, he sounds like a man determined to have either the joy of Ines' love or true death: 


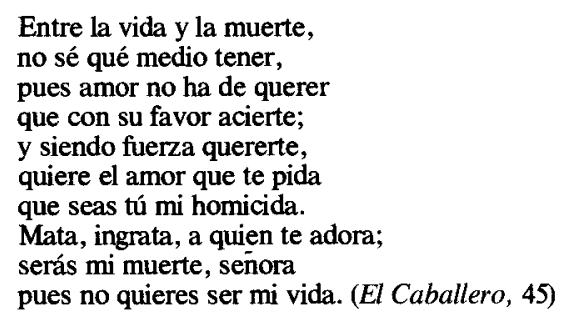

As Lope stated, "las décimas ... para quejas." The three décimas that form Rodrigo's pathetic tirade combine the dramatic force of a lament with the enchanting beauty of its musical verses. Don Rodrigo's offer of his life is far more than a histrionic gesture; it unmistakably symbolizes his suffering as intolerable. The tragedy of the situation is accentuated by Ines' inability or unwillingness to recognize the sincerity of her aspirant lover. Camus excels in underlining the dramatic impact of this passage: "Suspendu entre vie et mort, je ne sais quel parti prendre. L'amour ne m'obtiendra jamais tes faveurs et pourtant je ne puis m'empêcher de t'aimer. L'amour lui-même ne me laisse plus d'autre espoir que de mourir de tes mains. Tue donc, ingrate, celui qui t'adore et tu seras du moins ma mort, ô reine, puisque te ne veux pas être ma vie" (Théâtre, 736).

To compensate for the impossibility of reproducing the music of Lope's lines, Camus strengthens their pathetic violence. The past participle "suspendu," not found in the original text, creates an image of helplessness.

Even when the language of Lope's characters becomes somewhat stilted, Camus surprisingly respects the preciosity of the tone without destroying the spark of sincerity. Again we quote Rodrigo's slightly affected verses where he explains to Fernando that a perplexing paradox intensifies his misery:



Camus writes: "Oui, plus Inès m'accable de ses dédains et plus l'amour m'embrasse. Sans trêve, je me brûle à sa neige. O grilles mouillées de mes larmes, comment un ange peut-il traiter si durement celui qui amollit vos fers?" (Théâtre, 743). In spite of the apparent fidelity, Camus makes a couple of almost imperceptible changes that merit analysis. In the original, Ines not only burns Rodrigo with her "snow" but also flames up his soul. 
Camus does not put as much wood on the fire! Don Rodrigo burns "a sa neige" but only becomes more amorous with her disdain. Thus he removes a little of the affectation. The second variant could almost be used as a criticism since it results from a misinterpretation. In the Spanish version, the forlorn lover addresses the grill of Ines' garden to deplore a painfull paradox: he can soften the iron bars with his tears but fails to move an angel. Misled by the juxtaposition of "ángel" and "endureciera," Camus assumes "ángel" to be the subject and translates "comment un ange peut-il traiter si durement..." However, the French sentence is so smooth and clear that it might have been an intentional variation to improve the fluidity of his prose. Baret's translation also fails to preserve the original meaning: " $\mathrm{O}$ grilles qu'attendrissent mes plaintes, qui croirait qu'un ange fût sans pitié, quand la pitié peut amollir le fer de vos barreaux!" 10 But witness how much easier it is to read Camus' translation. The repetitive sounds of the consonants " $m$ " and " $n$ " in the latter give a melodious rhythm which facilitates recitation and creates an impression of softness and caress.

Most articles on Le Chevalier d'Olmedo applaud Camus translation of the dramatic and lyrical passages. But had he only succeeded in these areas his task would have been only half finished. Humour also plays a major role in Lope's comedias. The wanton mixture of pathos and bathos is as much part of this theater as its enchanting verses, its youthfulness, its energetic movement. To those who criticized him for this contrast of emotions, Lope, only half in jest, pointed out the variety found in nature. ${ }^{11}$ His plays reflected the natural; the classical ones, by their arbitrary isolation and development of one emotion, distorted reality. Any translator who wished to do justice to the Spanish playwright had to respect the original intentions regardless of his personal convictions. Baret, writing as if for seventeenth century audiences, did not. Camus did.

Critical reviews and studies attribute little importance to humor in Camus' version. They fail to comment on the scenes worthy of a Molière or, worse, they judge humor to be the play's weakest point. M. Costes, a professor of Spanish at the Sorbonne who praised the translation of the serious passages, believed that Camus did not give enough relief to some of the humorous techniques because: 'il semble qu'il n'ait pas toujours osé, par tempérament ou par crainte de heurter les goûts classiques du public français, transporter dans toute sa violence le contraste entre les scènes pathétiques et les intermèdes parodiques ou burlesques qui est l'un des traits fondamentaux du thêatre espagnol du XVIIème siècle." 12

We must disagree with this judgment. All humorous passages, replies, interjections, are preserved and in some cases they are even improved.

In the third scene of act II we are treated to pure lyricism. Tello, however, drags down to earth the divine language of the two lovers with his mundane interjections. The violence of the contrast, the dizzy descent from the sublime to the ridiculous, did not seem to upset Camus in the 
least. On the contrary, it required a mischievous delight to inject into Tello's amusing remarks all the parody of the original interruptions. With the tenderness that would melt the heart of any lover, Ines tells Alonso about the strange exchange that she has had with the flowers in her garden: she is jealous because at the end of each night they see their sun whereas she is often deprived of hers, Don Alonso. You should be pleased, a lily seems to answer, because the sun you adore also rises at night. At this romantic moment, Tello adds his own explanations: " $C$ 'est la réponse du grec à cet aveugle qui l'accablait de plaintes: 'Puisque la nuit a ses plaisirs, pourquoi te plaindre de ne pas voir'.' (Théâtre, 759) And when Don Alonso confesses to her that he has also been sharing his secrets and fears with the flowers, Tello seconds his master: "C'est un fait! Je l'ai vu déclarer son amour aux radis d'Olmedo" (Théâtre, 759). No attempt is made to soften the contrast, or to render the burlesque interjections more palatable to classical taste.

In translating humor, Camus was more than apt; he often improved the original by his understanding of the gracioso's role. The two Spanish plays he translated provide excellent examples of the two types of graciosos commonly appearing in the theater of the 17th century. Gil, in $L a$ Devoción de la cruz, is the typical simple peasant whose mental stupor, physical torpidity, and rustic language are at the origin of his humor, $\mathrm{He}$ is a ridiculous individual: we laugh at him, not with him. Tello, on the other hand, represents the other type of gracioso, at the zenith of development. Conscious of the situation in which he finds himself, comfortable in his ingenious domination of the language, proud to demonstrate his superior intelligence, he amuses himself and the audience with his subtle mind: he delights in smudging poetry with the banal colors of prosaic existence; he loves being the pace-setter of the action on stage.

Baret's exaggerated sense of propriety made him object to the importance given to the gracioso in El Caballero de Olmedo. Consequently he reduced it considerably. Camus, considering this character one of the outstanding figures of the play, not only respected his role, his importance, but restored the pungency to some of his remarks that had lost their bite.

In a scene pulsating with youthful joy, Tello tells his master how Fabia and himself were accepted by Don Pedro as his daughter's duenna and Latin teacher respectively. The servant's story is interrupted by Don Alonso's intermittent readings of a note from Ines. After reading each small segment, Alonso pauses, mystically savoring every precious word. At the first stop, Tello comments: " $i$ Es aquí contemplación?", the second elicits this remark: "¿Hay otra estación aquí?'. In Camus' text the first becomes: "Cet air-là, que vous prenez, je suppose que c'est l'air de l'adoration?". The mockery has increased. It becomes even more accentuated in the second observation: "Jésus tombe pour la deuxième fois!". 
Earlier in the play, when Tello persuasively presents his outstanding academic achievements to Don Pedro, Ines' father asks him where he studied. The aspiring Latin teacher answers: "En la Coruna, y soy por ella maestro." Camus changes it to: "Où avez-vous étudié? A la campagne et je suis docteur de cette université." M. Costes criticizes this variant as both strained and inadequate (Thêâtre, 1861). This is, we believe, unjust criticism.

The humour of the original remark is based on the fact that la Coruna, in spite of its size and importance, never had a university. A Spaniard, aware of this, could laugh at the imposture. The French public, however, would not even detect the lie. In making Tello say that he received his doctorate "a la campagne," Camus renders the reply ridiculous as envisaged by Lope de Vega. Here Camus respected the author's intention rather than the words but the result is most favorable. Camus, it is obvious, was more concerned about translating as efficaciously as possible Tello's comical and slightly irreverent interjections than he was about sparing the supposed delicacy of "les goûts classiques du public français."

Indeed, if anything, Camus could be faulted for being too faithful a translator. Lope, who often tried to please the rather uncouth mosqueteros, as the pit was often called, occasionally succumbed to vulgarity and crude humor. Such infelicitous moments are rare in $E l$ Caballero de Olmedo. However, those that did intrude are also to be found in Camus' version. On example should be sufficient to show that Camus' virtue, his fidelity, could have been his failing as well. In order to prepare emotionally Ines for a love letter from Alonso, Fabia recalls Don Pedro's passionate temperament and romantic escapades. The sorceress explains to the two young sisters that their father would often ask her to arrange amorous encounters with the women that caught his fancy. So strong and impetuous was his desire, in fact, that Fabia, out of respect for his wife, tried to restrain him: "Plus d'une fois, je vous le dis en confidence, Don Pedro m'a chargée de ses fredaines. Mais je portais trop de respect à celle qui est en train de pourrir, pour ne pas agir selon mon devoir. Sur dix filles qu'il demandait, je lui en refusais cinq" (Théâtre, 729).

In the original text, Fabia's comments on "la que pudre" are intended to encourage Ines to enjoy herself while she is still young and able. It is one of the arguments aimed at breaking down Ines' resistance. Thinking that Don Alonso's purpose is seduction, she attempts first to destroy her fear of and respect for her father, then to incite her to her pleasure, and finally to hint that she can repair any damage if the need arises. Today, however, these remarks seem more apt to spark her indignation than her desire. The image of the mother "en train de pourrir," and the story of her father chasing after young women to mitigate his insatiable lust, seem totally inappropriate to prepare a young lady for a love letter. One might perhaps wish that Camus had kept the intentions of the Spanish playwright without using the same imagery. 
Another weakness is also connected to his explicit desire to adhere as closely as possible to the original. Lope's text becomes so affectedly refined in some passages as to make literal translation impossible. Camus insists and stumbles awkwardly at various times. Because of its difficulty and preciosity, Don Alonso's long tirade at the beginning of the play (scene ii, Act I) causes Camus to weigh down his dialogue. Some of the original sentences are almost incomprehensible: "Con la caja de la boca/ allegaba infantería, / porque sin ser capitán / hizo gente por la villa. (El Caballero, 32) Camus managed to clarify it somewhat but unfortunately he kept the same metaphor: "Au tambour de sa bouche rieuse, une infanterie se rassemblait et, sans rien commander, elle recrutait dans la ville entière (Théâtre , 724). The juxtaposition of "tambour" and "bouche" creates a very unattractive image of Ines. And comparing her to a recruiting sergeant does not help to create an image of graceful femininity. Perhaps this sentence should not have survived transposition.

Camus stumbled once again in his translation of a passage where Don Alonso depicts the captivating power of Ines' hair. In the original her hair is described as "rizado el cabello en lazos, / que quiso encubrir la liga, / porque mal caerán las almas / si ven las redes tendidas (El Caballero, 32). In spite of its preciosity, this image has a certain charm which is destroyed by Camus' inexplicable addition of baroque elements: "Inès, comme si elle savait que les cœurs ne se piègent pas avec des rêts trop visibles, avait recouvert et huilé les noeuds de ses cheveux bouclés" (Théâtre, 724). The Spanish text does not state that Ines "covered and greased" her hair, but rather that her curls covered the ribbon. It is the ribbon, not her hair, which is said to be the net that catches enamored hearts. In all fairness to Baret, this entire passage is generally better in his translation. There is little doubt, however, that Camus' Le Chevalier d'Olmedo is by far the best French version of Lope's play.

Camus' significance as translator naturally pales when compared to his success, reputation, and achievement as novelist, thinker, and "homme engagé." But his accomplishments in the area of translation are by no means insignificant. His brilliant successes at the "Festival d'Angers" would attest to that. The accolades bestowed upon him for his translations and adaptations of Calderón's La Devoción de la cruz and Lope de Vega's El Caballero de Olmedo were not restricted to the excellent "mise en scène" or to the superb décor and natural stage provided by the Angers castle; they also paid tribute to excellent texts. Texts that managed to respect the authors' intentions and language without sounding exclusively foreign, artificial, and dated; texts that facilitated the actor's role and were accessible to the audience. Our present study corroborates the initial reaction of critics and audiences alike. Camus' Le Chevalier d'Olmedo succeeds where he most desired to succeed: it provides a play whose language retains the music and poetic beauty of the original but allows French actors to reproduce it "commodément." 
Menéndez Pelayo believed that the Spanish theater of the Golden Age could not be expected to win universal admiration because "está demasiado pegado a nuestra raza para que pueda parecer natural y simpático a otros pueblos: a duras penas, y en fuerza de su desinterés estético y de proceder por líneas generales, los alemanes han llegado a identificarse con él; los ingleses nunca; se han quedado con Shakespeare; y los franceses con Molière." 13 To claim that Camus' translation belie Pelayo's pessimistic judgment would be to exaggerate their importance. Camus, however, must be credited on two accounts. To begin with he recognized the universal values of these works: the glorification of courage and heroism, the exaltation of human grandeur, the vivid affirmation that life deserves to be lived, are not confined by national bounderies. Furthermore, by providing an excellent theatrical version, Camus proved that a French public could give a warm welcome to this foreign and nationalistic theater. He found fertile soil north of the Pyrenees for this art which Pelayo believed too strongly rooted on Spanish soil to survive transplantation.

University of Michigan, Dearborn

MANUEL A. ESTEBAN

\section{Notes}

1. This topic was suggested to me by my brother, Julio Esteban, who did much of the initial research.

2. Robert Kemp, "Un festival Albert Camus: Caligula, Le Chevalier d'Olmedo," L'Express, no. 314 (June 28, 1957), p. 22.

3. Albert Camus, Théâtre, Recits, Nouvelles, ed. Roger Quilliot (Bruges: Editions Gaillimard; Bibliothèque de la Pléiade, 1967), p. 1855. Subsequent references to this edition will appear in the text.

4. Lope de Vega, El Caballero de Olmedo (eight edition; Zaragoza: Editorial Ebro, 1966), p. 29. Subsequent references to this edition will appear in the text.

5. Lope de Vega, Obras Escogidas. Poesias líricas, poemas, prosa, novelas (third edition; Madrid: Aguilar, 1961), II, 895.

6. Note the lack of dramatic force in Don Alonso's monologue: " 1 'amour qui dans mon âme entretient une flamme si vive, est né des subtils esprits contenus dans deux beaux yeux. Leur regard n'exprimait pas le dédain; loin de là, leur douce expression me donna tant de confiance, que je me mis à espérer, dans la pensée d'un tendre retour." Eugène Baret Oeuvres dramatiques de Lope de Vega (Paris: Didier, 1869), p. 211.

7. Obras escogidas, p. 895.

8. Ibid., p. 896. In his Arte nuevo, Lope writes: "Pero ¿qué puedo hacer, si tengo escritas/con una que acabo esta semana,/cuatrocientas y ochenta y tres comedias?"

9. Ilona Cooms, Camus, homme de théâtre (Paris: Nizet, 1968), 146.

10. Baret, pp. 224225 .

11. Obras, escogidas, p. 894.

12. M. Costes was asked by Roger Quilliot to evaluate Camus' translations. His opinions are summarized in Théâtre, pp. 1860-61.

13. Marcelino Menéndez Pelayo, Teatro: Lope, Tirso, Calderón (Santander: Edición Nacional de las obras completas de Menéndez Pelayo, 1941), III, p. 129. 